\title{
Analysis of the global market of technologies in the field of collection, sorting and recycling of polymer waste
}

\author{
Anna Starodubova ${ }^{1, *}$, Dinara Iskhakova $^{1}$, and Chulpan Misbakhova ${ }^{1}$ \\ ${ }^{1}$ Kazan National Research Technological University, 420015, Kazan, Russia
}

\begin{abstract}
The authors propose a method for evaluating the market of technologies for the collection, sorting and recycling of polymer waste. The novelty of the study is classification of technologies for the collection, sorting and recycling of polymer waste. It is base on the principles of "Circular Economy". The authors proposed an algorithm for calculating the specialization index of technologies. A patent search for calculating the specialization index performed based on this classification. The author's method was the analysis of 17 countries at the beginning of 2021. These countries are owners of patents of technologies for the collection, sorting and recycling of polymer waste. The study reveals that the global market of technologies for the collection, sorting and recycling of polymer waste is formed only by $50 \%$ of the average level of the specialization index. The leaders in the specialization index are the USA, China and European Union. This evaluation of market allows us to determine the effectiveness of the waste management strategy. The authors offer two options. For countries with high specialization index, we suggest the strategy of differentiation. This strategy is to develop a comprehensive technology of plastic waste management. For countries with a low specialization index, we suggest the strategy of focusing. This strategy is to develop novel technologies on the basis of "Circular Economy".
\end{abstract}

\section{Introduction}

Currently, polymer waste management is a widely discussed topic in the world. The countries of the world recognize the need for effective polymer waste management. However, technologies for recycling polymer waste in various countries are developing at different rates. Also, not all countries in the world consider the principles of sustainable development. Such a difference is clearly visible in the report World Bank's in the level of recycling among other methods of plastic waste management (see figure 1) [1].

It is necessary to perform an integrated study of the advantages and weaknesses for all technologies for polymer waste treatment. This study should consider deviations from the principles of the "Circular Economy". Therefore, countries need to develop strategies to achieve this goal. This illustrates the relevance of the topic of this study.

The purpose of the paper is to study the global market of technologies for polymer waste and the factors that determine its progress.

The objects of the study are the countries that are patent holders of technologies for polymer waste treatment at the beginning of 2021.

The subject of this study is the specialization index of technologies for the collection, sorting and recycling of polymer waste at the beginning of 2021 on the global market.
The hypothesis of the research is that the waste management strategies of countries depend on the level of the specialization index of technologies. A more effective strategy for the waste management is achieved for the high specialization index of technologies.

According to the authors, a fully formed market is the one which the specialization index is greater than or equal to 0.5 rel. units.

Taking this factor into account would allow the state to regulate the rate of formation of polymer waste.

\section{Materials and methods}

Currently, there are few scientific papers on the analysis of the market of technologies for the collection, sorting and recycling of polymer waste. In particular, there are few articles about equipment suppliers. There is no information: about producers by country, by type of polymer waste, and market barriers.

World Intellectual Property Organization is the only source on patents of such technologies. This organization does not have a lot of relevant data and comprehensive research materials on technologies for polymer waste. For example, in 2013, a study published by WIPO together with the Basel Convention. This report is dedicated to some specific technologies for polymer waste such as individual waste of electronic equipment [2]. This study describes the manufacturers of final products in the field of electronics by country and the type of recyclable materials [2].

\footnotetext{
* Corresponding author: upfr-nk@list.ru
} 

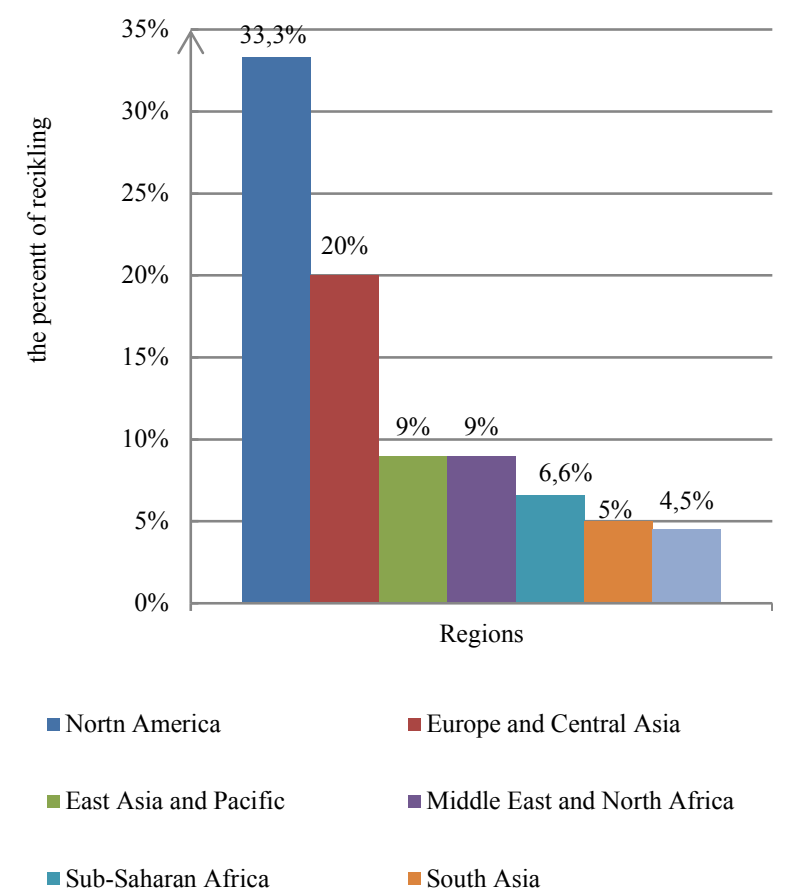

Latin America and Caribbean

Fig. 1. The level of recycling of regions in total methods of waste management for plastic in 2018 year.

Also, WIPO publishes the annual review "WIPO GREEN". This report includes the names of enterprises engaged in green technologies. However, this report contains only general information about green technologies. For example, it has not enough information about polymer waste [3].

A website "WIPO GREEN" contains a database on the offer of enterprises in the field of green technologies. There is also no information for polymer waste. The number of proposals in this database of waste recycling is not considerable [4].

The authors reporting polymer waste management technologies are K. Jaidev, M. Biswal, S. Mohanty, S. K. Nayak, A. Samuila, L. Dascalescu, L. Calin, M. Bilici, A. Catinean, R. Cherrington and K. Makenji [5], [6], [7]. These authors describe the methods for recycling of waste from electronic equipments.

Papers that describe technologies for recycling of waste from electronic equipment occupy a biggest share among papers focused of polymer waste management.

C. Signoret, A. S. Caro-Bretelle, J. M. Lopez-Cuesta, P. Ienny, D. Perrin, L. Milios, L. Holm Christensen, D. McKinnon, M. K. Rasch, M. Hallstrom Eriksen agree that the sorting process causes the most problems [8], [9]. Recycling of polypropylene and polyethylene is studied in more details [10].

There are a notable number of studies on the recycling of mixed waste. For example, these are papers focus on the pyrolysis and the recycling of composite materials (fiberglass and carbon fiber) [11], [12], [13].

A small number of researchers compare the methods of recycling polymer waste (the advantages and the disadvantages) [14], [15].
The remaining studies of technologies in the field of polymer waste are devoted to factors that affect the level of recycling. For example, the dependence of the level of recycling in the European Union on the amount of investment in R \& D is revealed in [16], [17]. Many researchers believe that the development of technologies for waste recycling depends on the number of urbanized populations in the country [17]. This information is presenting in the "What a Waste 2.0" report of the World Bank. Earlier in the study, we also studied the factors that affect the level of waste management in the world [18]. One of these factors is the cost of waste management [18]. In our opinion, these factors are barriers on the market of technologies for the collection, sorting and recycling of polymer waste.

Since 2015, research activities in technologies for polymer waste are guided by the principles of the «Circular Economy» [19], [20], [21], [22], [23], [24], [25]. These papers describe possible options for a closed cycle for polymer products including processes at production, consumption, and utilization stages.

This study consisted of the following stages.

At the first stage of the study, an algorithm is proposed for calculating the specialization index of technologies for the collection, sorting and recycling of polymer waste on the global market. At the same time, this specialization index considers the principles of «Circular Economy».

At the second stage of the study, a patent search was conducted for the data needed to calculate the specialization index according to the author's methodology at the beginning of 2021.

At the third stage of the study, we calculated the specialization index for countries at the beginning of 2021. These countries were the patent holders of technologies for the collection, sorting and recycling of polymer waste in the world market.

\section{Results}

At the first stage of the study, the authors developed an algorithm for calculating the specialization index. For this purpose, the authors defined the term "specialization". Specialization of technologies is a set of types of technologies for the collection, sorting and recycling of polymer waste developed and patented by the country. The specialization index is a relative indicator. The authors proposed to calculate it by algorithm that divides the number of types of technologies in the country by the total number of types of technologies in the world.

The authors conducted a review of patents for the beginning of 2021. It was been needed for determine the total number of types of technologies for the collection, sorting and recycling of polymer waste [26]. According to this source, the authors identified the following features of technologies for the collection, sorting and recycling of polymer waste.

What stage of waste management is this technology intended for?

What material is processed by this technology? 
What methods of waste recycling are used in this technology?

All these features have been proposed by the authors as criteria. They were necessary for determining the total number of types of technologies for polymer waste.

Scientific studies determinate that some polymer materials can harm the environment and public health [27]. The authors make such a conclusion following the principles of the "Circular Economy". It is necessary to excluding the types of technologies that harm the environment and public health in calculations.

At the second stage of the study, a patent search was conducted in the World Intellectual Property Organization database [26]. The selection was carried out according to the criteria proposed at the first stage of the study. The data were selected from the materials corresponding to the beginning of 2021. The authors have obtained the following results. 15 countries have patented the developed the technologies for the collection, sorting and recycling of polymer waste; in total, there are 29 active types of technologies for the collection, sorting and recycling of polymer waste in the global market (see Table 1).
Table 1. Types of technologies for the collection, sorting and recycling of polymer waste at the beginning of 2021 in the global market.

\begin{tabular}{|c|c|}
\hline $\begin{array}{l}\text { Depending on } \\
\text { the stage of } \\
\text { waste } \\
\text { management } \\
\end{array}$ & $\begin{array}{l}\text { Depending on the material to be } \\
\text { recycling and/ or the recycling method }\end{array}$ \\
\hline $\begin{array}{l}\text { waste } \\
\text { collection }\end{array}$ & recycling of PP, PS, PE with a solution \\
\hline $\begin{array}{l}\text { sorting of } \\
\text { waste }\end{array}$ & $\begin{array}{l}\text { recycling of PP, PS, PE by mechanical } \\
\text { method and thermoforming }\end{array}$ \\
\hline \multirow{24}{*}{$\begin{array}{l}\text { cleaning, } \\
\text { drying of waste }\end{array}$} & $\begin{array}{l}\text { recycling of PP, PS, PE by pyrolysis } \\
\text { (output: hydrocarbon liquid and pyrolysis } \\
\text { gas) }\end{array}$ \\
\hline & recycling of PP, PS, PE by oxidation \\
\hline & $\begin{array}{l}\text { recycling of PE-based textiles by the } \\
\text { solution method }\end{array}$ \\
\hline & $\begin{array}{l}\text { recycling of other PET materials, by } \\
\text { mechanical method and thermoforming }\end{array}$ \\
\hline & $\begin{array}{l}\text { recycling of other PET materials by the } \\
\text { solution method }\end{array}$ \\
\hline & recycling of PVC with a solution \\
\hline & recycling of PVC by pyrolysis \\
\hline & mechanical recycling of PVC \\
\hline & recycling of ABS with a solution \\
\hline & mechanical recycling of ABS \\
\hline & recycling of PU with a solution \\
\hline & mechanical recycling of PU \\
\hline & $\begin{array}{l}\text { recycling of PU by pyrolysis (output: } \\
\text { hydrocarbon liquid and pyrolysis gas) }\end{array}$ \\
\hline & $\begin{array}{l}\text { recycling of other elastomers with a } \\
\text { solution }\end{array}$ \\
\hline & mechanical recycling of other elastomers \\
\hline & recycling of mixed polymers (electronic) \\
\hline & $\begin{array}{l}\text { recycling of other mixed polymers by } \\
\text { solution }\end{array}$ \\
\hline & $\begin{array}{l}\text { recycling of other mixed polymers by } \\
\text { pyrolysis (output: hydrocarbon liquid and } \\
\text { pyrolysis gas) }\end{array}$ \\
\hline & $\begin{array}{l}\text { recycling of other mixed polymers by } \\
\text { steam cracking }\end{array}$ \\
\hline & recycling of the film with a solution \\
\hline & film recycling by thermoforming \\
\hline & film recycling by flotation \\
\hline & $\begin{array}{l}\text { recycling for the extraction of cellulose } \\
\text { from plastic }\end{array}$ \\
\hline & $\begin{array}{l}\text { recycling for the production of materials } \\
\text { for } 3 \mathrm{D} \text { printing, by mechanical method } \\
\text { and thermoforming }\end{array}$ \\
\hline
\end{tabular}

According to the "Circular Economy" concept, the authors excluded certain types of technologies for the reason, that it can exert a negative effect on the health of population. These are three types of PVC technology for recycling (Table 1).

At the third stage of the study, we calculated the specialization indices by the algorithm proposed at the first stage of the study.

We took the total number of types of technologies for polymer waste. This information was necessary to calculating the specialization index. The date was found at the second stage of the study. These were 26 types of technologies in the global market. This number did not include 3 types excluded earlier (see Table 1). We took the number of types of technologies for the collection, 
sorting and recycling of polymer waste in a country. This date was necessary to calculate the specialization index. This information was obtained at the second stage of the study for 15 countries. Then, the authors have performed a calculation of the number of types of technologies. There was the rule for calculation. If country possessed the one among the 26 types of technologies, the country was assigned 1 rel. unit. If country did not possess such the technologies, the country assigned 0 rel. unit (Table 1).

Table 2 presented the calculated indicators for countries of survey. These are the number of types of patented technologies and the specialization indices.

Table 2. The specialization indices of technologies for the collection, sorting and recycling of polymer waste on the global market at the beginning of 2021 .

\begin{tabular}{|l|c|c|}
\hline Country & $\begin{array}{c}\text { Number of types } \\
\text { of patented } \\
\text { technologies }\end{array}$ & $\begin{array}{c}\text { Specialization } \\
\text { index, rel.ed. }\end{array}$ \\
\hline China & 20 & 0.77 \\
\hline USA & 20 & 0.77 \\
\hline EU & 14 & 0.54 \\
\hline $\begin{array}{l}\text { Russian } \\
\text { Federation }\end{array}$ & 10 & 0.38 \\
\hline Australia & 7 & 0.27 \\
\hline Canada & 6 & 0.23 \\
\hline $\begin{array}{l}\text { Republic of } \\
\text { Korea }\end{array}$ & 4 & 0.15 \\
\hline India & 4 & 0.15 \\
\hline Malaysia & 4 & 0.15 \\
\hline Japan & 3 & 0.12 \\
\hline Great Britain & 2 & 0.08 \\
\hline Mexico & 2 & 0.08 \\
\hline Israel & 1 & 0.04 \\
\hline Saudi Arabia & 1 & 0.04 \\
\hline South Africa & 1 & 0.04 \\
\hline
\end{tabular}

According to Table 2, the average specialization index for all 15 countries is 0.25 rel. units. It has been calculated by the arithmetic mean.

\section{Discussion}

The market is considered to be completely formed if the specialization index was equal to or more than $0.5 \mathrm{rel}$. units. This is the hypothesis of our study. According to the results of Table 2, such markets have been formed in China, USA, and the European Union.

Also, a high level of specialization index indicates market power among other participants.

The remaining markets in 12 countries of study have not yet been formed to completion as their specialization indices were less than 0.5 rel. units. In total, the global market for polymer waste technologies not fully developed: its average specialization index is less than 0.5 rel. units. It was development degree is about $50 \%$ of the average level at the beginning of 2021.

According to M. Porter, competitive strategies can be based on:

- differentiation leadership;

- costs leadership;

- focus leadership [28].
Only 3 countries had a strategy of differentiation leadership on the market (see Table 2).

Only a country with low costs of technologies can have a cost leadership of strategy. At the same time, this country must meet the condition of the "Circular Economy". The global market did not have such participants that meet these criteria.

Japan was implemented the strategy of focus leadership and the "Circular Economy". Thus, Japan was met all these conditions.

The rest of the countries did not have a clear strategy on the global market of technologies for the collection, sorting and recycling of polymer waste. If, a country did not have a clear strategy leadership, then this is a barrier (or a threat) to it on the global market [28]. Many countries implement outdated technologies for polymer waste. Also, they did not follow the principles of "Sustainable development" (see Table 1).

The authors have made this conclusion based on the number of countries that own patents. That the technologies of recycling for the PE, PP, PS wastes took the 1st place. 11 countries had these technologies. The technologies for recycling of ABS and mixed composites and waste collection took the 2 nd place. 7 countries have such technologies.

The technologies for recycling PET, elastomers, and film took the 3 rd place. Also, this place was given to the technologies of the extracting for cellulose from plastic. 5 countries have such technologies.

The technologies for recycling the materials used for 3 D-printing and PE textiles are not studied to completion as well as the technologies of the sorting and cleaning of waste. Only, 3 countries have such technologies.

The hypothesis put forward by the authors was confirmed. More effective strategies of the waste management were achieved in countries with a high level of the specialization index.

The practical significance of the study was to reveal the factor will allow regulating of waste at the macroeconomic level. The number of researches about the analysis of the market of technologies for polymer waste is not considerable. An annual study of the market analysis for technologies to the author's method will allow conducting a foresight for a country. This foresight will include the opportunities and the threats for technologies.

Here are the perspectives of the research. Most countries cannot realize a waste management strategy with a high level of specialization index. Thus, for such countries, it is necessary to find new models for waste management. This is model should consider individual characteristics of the country.

Countries that occupy small territories export their waste for recycling to other countries. For this reason, such countries are leading in the development of innovative technologies. And also, they are considering the principles of sustainable development.

In our opinion, it is necessary to develop the abovementioned less studied areas and also look for emerging technologies for the collection, sorting and recycling of polymer waste. 


\section{Conclusion}

Thus, we can conclude that most of the polymer waste can be recycled. However, significant financial resources required to achieve the entire waste management cycle. One way of dealing with this problem is to use all waste during processing in the general flow. This method will allow countries to use the product of processing one waste an auxiliary element as for processing another. In our opinion, countries with a high specialization index could achieve this goal. These countries are China, USA and European Union.

\section{References}

1. Report «What a Waste 2.0» of International Bank for Reconstruction and Development [Electronic resource] (2018) Available at: https://openknowledge.worldbank.org/bitstream/ha ndle/10986/30317/211329ov.pdf?sequence=

2. Patent Landscape Report on «E-Waste Recycling Technologies» [Electronic resource] (2013) Available at: https://www.wipo.int/edocs/pubdocs/en/patents/948 /wipo_pub_948_4.pdf

3. Year in Review 2019 «WIPO GREEN» [Electronic resource] (2020) Available at: https://www.wipo.int/edocs/pubdocs/en/wipo_pub_ 1058_2019.pdf

4. The base of data of the «WIPO GREEN» [Electronic resource] Available at: https://www3.wipo.int/wipogreen-database

5. K. Jaidev, M. Biswal, S. Mohanty, S.K. Nayak, Sustainable Waste Management of Engineering Plastics Generated from E-Waste: A Critical Evaluation of Mechanical, Thermal and Morphological Properties, Journal of Polymers and the Environment (2021)

6. A. Samuila, L. Dascalescu, L. Calin, M. Bilici, A. Catinean, Recent researches in electrostatic separation technologies for the recycling of waste electric and electronic equipment, AIP Conference Proceedings, 2218, 030001 (2020)

7. R. Cherrington, K. Makenji, Mechanical methods of recycling plastics from WEEE (Book Chapter (Waste Electrical and Electronic Equipment (WEEE) Handbook, 2019, 283-310)

8. C. Signoret, A.S. Caro-Bretelle, J.M. LopezCuesta, P. Ienny, D. Perrin, Alterations of plastics spectra in MIR and the potential impacts on identification towards recycling, Resources, Conservation and Recycling, 161, 104980 (2020)

9. L. Milios, L. Holm Christensen, D. McKinnon, M.K. Rasch, M. Hallstrom Eriksen, Plastic recycling in the Nordics: A value chain market analysis, Waste Management, 76, 180-189 (2018)

10. G.D. Mumbach, A. Bolzan, R.A.F. Machado, A closed-loop process design for recycling expanded polystyrene waste by dissolution and polymerization, Polymer, 209, 122940 (2020)
11. L. Bertrand. A solution for multi component, laminated and dirty mixed waste plastics (surfaceflash-cracking), Proceedings of the Air and Waste Management Association's Annual Conference and Exhibition, AWMA (2019)

12. R.E. Allred, J.M. Gosau, Plant requirements for large-scale chemical recycling of composite materials, CAMX 2016 - Composites and Advanced Materials Expo (2016)

13. V. Sommer, G. Walther, Recycling and recovery infrastructures for glass and carbon fiber reinforced plastic waste from wind energy industry: A European case study, Waste Management, 121, 265-275 (2021)

14. J. Datta, P. Kopczynska, From polymer waste to potential main industrial products: Actual state of recycling and recovering, Critical Reviews in Environmental Science and Technology, 46 (10), 905-946 (2016)

15. A. Lee, M. Shan Liew, Tertiary recycling of plastics waste: an analysis of feedstock, chemical and biological degradation methods, Journal of Material Cycles and Waste Management, 23, 2-43 (2021)

16. D. Sultanova, A. Maliashova, L. Abzalilova, R. Sultanova, The main obstacles for development of international activity with russian-european chemical clusters: environ-mental aspect, E3S Web of Conferences: ICEPP 2020, 161 (2020)

17. A. Khaertdinova, D. Sultanova, D. Iskhakova, A. Karimov, Recycling of Polymers - An Opportunity or a Threat to the Economy?, E3S Web of Conferences: ICEPP 2020, 161 (2020)

18. A. Starodubova, D. Sultanova, A. Karimov, The concept of balanced development of waste management, E3S Web of Conferences: ICEPP 2020, 161 (2020)

19. C. Matthews, F. Moran, A.K. Jqiswal, A review on European Union's strategy for plastics in a circular economy and its impact on food safety, Journal of Cleaner Production, 283 (2021)

20. F. Casarejos, C.R. Bastos, C. Rufin, M.N. Frota, Rethinking packaging production and consumption vis-à-vis circular economy: $\mathrm{A}$ case study of compostable cassava starch-based material, Journal of Cleaner Production, 201, 1019-1028 (2018)

21. J.N. Hahladakis, E. Lacovidou, Closing the loop on plastic packaging materials: What is quality and how does it affect their circularity?, Science of the total environment, 630, 1394-1400 (2018)

22. J. Payne, P. Mckeown, M.D. Jones, A circular economy approach to plastic waste, Polymer Degradation and Stability, 165, 170-181 (2019)

23. M. Robaina, K.Murillo, E. Rocha, J. Villar, Circular economy in plastic waste - Efficiency analysis of European countries, Science of the total environment, 730, 139038 (2020)

24. K. Joachimiak-Lechman, D. Garstecki, M. Konopczynski, A. Lewandowska, Implementation of Life Cycle Based Tools in the Circular Economy Context - Case Study of Plastic Waste, Sustainability, 12 (23), 9938 (2020) 
25. E. Gubanova, L. Kupinets, H. Deforzh, V.Koval, $\mathrm{K}$. Gaska. Recycling of polymer waste in the context of developing circular economy, Architecture, Civil Engineering, Environment, 12 (4), 99-108 (2020)

26. The base of data of the «World Intellectual Property Organization» [Electronic resource] Available at: https://patentscope.wipo.int/search/en/search.jsf

27. The base of data of the «REACH» [Electronic resource] Available at: https://ec.europa.eu/growth/sectors/chemicals/reach en

28. $\bar{M}$. Porter, M. Kramer, Creating shared value: How to reinvent capitalism and unleash a wave of innovation and growth (Harvard Business Review, 2011, 62-77). 